УДК 336:331.1

Карлін Микола,

доктор економічних наук, професор, Волинський національний університет імені Лесі Українки, професор кафедри фінансів

м. Луцьк; ORCID ID 0000-0002-1421-1066 e-mail: karlin.lutsk@gmail.com

https://doi.org/10.29038/2786-4618-2021-02-87-93

\title{
ФІНАНСОВІ ПОРУШЕННЯ ПРИ ПРОВЕДЕННІ ПУБЛІЧНИХ ЗАКУПІВЕЛЬ В УКРАЇНІ ТА ЗАСОБИ ЇХ МІНІМІЗАЦІї
}

В статті розкриті причини та особливості прояву фінансових порушень при здійсненні публічних закупівель в Україні; досліджені фінансові проблеми, які існують в Україні при проведенні тендерних закупівель, а також проблеми у діяльності контролюючих структур країни в царині здійснення публічних закупівель. В статті також обгрунтовуються напрями реформування механізму здійснення фінансового контролю за проведенням публічних закупівель в Україні з урахуванням досвіду країн Свропейського Союзу; виявлені фінансові особливості здійснення публічних закупівель після вступу у дію нової редакції Закону України «Про публічні закупівлі»; досліджені форми фінансової відповідальності учасників та замовників публічних закупівель в Україні та їх ефективність.

Ключові слова: публічні фінанси, публічні закупівлі, фінансові порушення, фінансова відповідальність учасників тендерів, Свропейський Союз, Польща, Україна.

Карлин Николай, доктор экономических наук, профессор, Волынский национальный университет имени Леси Украинки, профессор кафедры финансов, г. Луцк

\section{ФИНАНСОВЫЕ НАРУШЕНИЯ ПРИ ПРОВЕДЕНИИ ПУБЛИЧНЫХ ЗАКУПОК В УКРАИНЕ И СПОСОБЫ ИХ МИНИМИЗАЦИИ}

В статье раскрыты причины и особенности проявления финансовых нарушений при осуществлении публичных закупок в Украине; исследованы финансовые проблемы, которые существуют в Украине при проведении тендерных закупок, а также проблемы в деятельности контрольных структур страны в области осуществления публичных закупок. В статье также обосновываются направления реформирования механизма осуществления финансового контроля за проведением публичных закупок в Украине с учетом опыта стран Европейского Союза; выявлены финансовые особенности осуществления публичных закупок после вступления в силу новой редакции Закона Украины «О публичных закупках»; исследованы формы финансовой ответственности участников и заказчиков публичных закупок в Украине и их эффективность.

Ключевые слова: публичные финансы, публичные закупки, финансовая ответственность участников тендеров, Европейский Союз, Польша, Украина.

Mykola Karlin Doctor of Economic Sciences, Full Professor, National University Head of the Department of Finance,

Lutsk

\section{FINANCIAL VIOLATIONS IN THE IMPLEMENTATION PUBLIC PROCUREMENT IN} UKRAINE AND MEANS OF MINIMIZING THEM 
The article reveals the features of the manifestation of financial violations in the implementation of public procurement in Ukraine and their causes; the financial problems that exist in Ukraine during the tender procurement as well as the problems in the activities of the regulatory authorities of the country during the control of public procurement were studied. The directions of reforming the mechanism of financial control over the implementation of public procurement in Ukraine, taking into account the experience of the European Union were substantiated in the article; financial features of the implementation of public procurement after the entry into force of the new version of the Law of Ukraine "On Public Procurement" were detected; the forms of financial responsibility of participants and customers of public procurement in Ukraine as concerns of their effectiveness were studied; ways to increase their effectiveness were proposed.

Public procurement has become the largest market in Ukraine so it is necessary to achieve maximum efficiency from their implementation minimizing the existing shortcomings. Among them experts single out the following: corruption, low professional level of customers, paying little attention to the financial capacity of borrowers, imperfect legal regulation of qualification selection of borrowers, the predominance of price criteria when choosing a winner, lengthy tender procedure, insufficient provision of office equipment and Internet to work with ProZorro system as well as the existence of financial violations by customers and participants in public procurement in Ukraine. It stipulates the necessity to strengthen the financial responsibility on the part of all tenderers as both customers and suppliers commit certain abuses during tenders.

The main shortcomings of financial control in the field of public procurement in Ukraine include duplication of functions of the State Audit Service and the Accounting Chamber; lack of a clearly defined methodology for controlling public procurement; the predominance of the next type of control over the previous one; lack of a clear mechanism for cooperation between law enforcement and regulatory authorities in the field of public procurement, etc. Another problem in Ukraine is that public control in the field of public procurement is not widespread enough. The implementation of the measures proposed by the authors to correct these shortcomings will achieve to increase the efficiency of public procurement in Ukraine and strengthens the financial responsibility of their participants. One of the main ones should be the prevention of financial violations in public procurement in Ukraine.

Key words: public finance, public procurement, financial violations, financial responsibility of tenderers, European Union, Poland, Ukraine.

Постановка проблеми у загальному вигляді i iї зв'язок 3 важливими науковими та практичними проблемами. В системі публічних фінансів України з кожним роком зростає роль $\mathrm{i}$ значення публічних закупівель, які вже перетворилися на найбільший ринок нашої країни, який перевищує 700 млрд грн.

Тому необхідно добиватися максимальної ефективності від їх проведення, мінімізуючи існуючі недоліки. Це обумовлює необхідність посилення фінансової відповідальності з боку їх учасників та контролюючих структур. До основних недоліків фінансового контролю у сфері публічних закупівель в Україні відноситься дублювання функцій Державної аудиторської служби та Рахункової палати; відсутність чітко прописаної методології контролю за публічними закупівлями; переважання наступного виду контролю над попереднім; відсутність чіткого механізму взаємодії правоохоронних та контролюючих органів у сфері здійснення публічних закупівель тощо. Проблемою в Україні $є$ й те, що недостатньо поширеною практикою $є$ здійснення громадського контролю у сфері публічних закупівель. Запровадження нової редакції Закону України «Про публічні закупівлі» в 2020 р. дозволило підвищити їх ефективність, але не в повній мірі знизило фінансові ризики при їх проведенні.

Аналіз останніх досліджень і публікацій. 3 кожним роком все більше зарубіжних та українських вчених і практиків шукають нові підходи до вирішення проблем підвищення фінансової ефективності публічних фінансів. Теоретичні та методологічні основи удосконалення використання публічних закупівель у країнах світу та в Україні дослідили такі зарубіжні та українські вчені, як: Г. Азаренкова, М. Білуха, І. Бондар, А. Бойєр, А. Брендон-Джонс, А. Буряченко, О. Воробйова, В. Горин, А. Давіл, Т. Жибер, О. Міщенко, Т. Мороз, В. Морозов, Д. Кауфман, Й. Матечак, А. Олефір, Н. Панайотоу, О. Рижова, І. Сидоренко, Дж. Стігліц, Н. Ткаченко, Г. Харченко, А. Хайнеманн, А. Храмкін, В. Чабан, І. Чорна, Р. Шаппер. Водночас, проблематиці мінімізації фінансових порушень при проведенні тендерних закупівель поки не приділяється належної уваги, що пояснюється складністю їх визначення та покарання за них. 
Мета та завдання статті. Метою статті $є$ розкриття основних особливостей фінансових порушень при здійсненні публічних закупівель в Україні з боку замовників і учасників та виявлення шляхів їх подолання, що дозволить підвищити ефективність використання публічних фінансів нашої країни. Відповідно, завданнями статті $\epsilon$ виявлення різних видів фінансових порушень при проведенні тендерів; обгрунтування різних форм фінансової відповідальності замовників та виконавців за фінансові порушення при проведенні публічних закупівель; удосконалення форм контролю державних структур та громадських організацій за порядком проведення тендерних закупівель на всіх рівнях.

Викладення основного матеріалу і обгрунтування отриманих результатів дослідження. Держава в умовах розвитку ринкової економіки в Україні виступає досить потужним споживачем товарів, робіт і послуг. Тому важливо підвищити ефективність проведення публічних закупівель та посилити контроль за ними. На це направлена нова редакція Закону України «Про публічні закупівлі», яка почала діяти 3 квітня 2020 р. 3 цієї дати всі замовники публічних закупівель у нашій країні зобов'язані публікувати в системі Prozorro повну інформацію про всі свої закупівлі. Загалом, у 2020 р. завдяки використанню системи Prozorro державі вдалося заощадити близько 43 млрд грн, що на 43 \% було більше, ніж в 2019 р. [1]. Система Prozorro інтегрована 3 Державним ресстратором лікарських засобів, взаємодіє 3 Державною фіскальною службою (ДФС) та Державною казначейською службою (ДКС), що зменшує ризики прояву фінансових правопорушень при здійсненні публічних закупівель.

Згідно з новою редакцією Закону України «Про публічні закупівлі», спрощені закупівлі від 50 тис грн до порогу відбуваються без аукціону на зниження ціни. Якщо пропозиції подають два чи більше учасників, то аукціон відбувається, а якщо учасник один, то замовник може зразу підписати договір з ним. У такий спосіб вже проведено понад 260 тис закупівель і зекономлено майже 3 млрд грн. Водночас, дослідження експертів показало, що і замовники, і учасники не до кінця задоволені спрощеною процедурою [2]. Поки спрощені закупівлі стають непростими часто через самих замовників, які вимагають від учасників багато зайвих документів, що призводить до зростання скарг до АМКУ. У той же час, після запровадження нової редакції Закону України «Про публічні закупівлі» приблизно $60 \%$ скарг з боку учасників стали задовольнятися [3]. Крім того, для скорочення витрат часу для замовників нещодавно в Prozorro Market запрацював запит ціни пропозицій, що дозволяє замовникам не лише купувати швидко, а й заощаджувати свої кошти. На наш погляд, для зменшення проблем із ширшим залученням виконавців до проведення спрощених закупівель (частина 3 них не хоче займатися останніми через значне витрачання часу на їх підготовку та проведення) було б доцільним щорічно збільшувати поріг спрощених закупівель хоча б на рівень інфляції.

Нові зміни у законодавстві щодо публічних закупівель поки не в повній мірі працюють в Україні, і досить часто їх порушують самі замовники. Прикладів цьому достатньо, насамперед при будівництві доріг та дорожньої інфраструктури, про що постійно повідомляють загальнодержавні та місцеві 3МІ. Широко відомий факт про те, як керівник тернопільського автодору, щоб обійти Prozorro, розбив семи кілометровий відрізок однієї дороги на ділянки по 40 метрів, уклавши 177 договорі на ремонт. В кінці 2020 р. був звільнений директор державного підприємства «Служба автомобільних доріг у Волинській області» I. Свиридов, оскільки керівництво цієї структури небезпідставно підозрювалося громадськістю у тіньовому характері проведенні тендерів. Крім того, при I. Свиридові умови тендерів на ремонт доріг у багатьох випадках прописувалися так, що їх вигравала одна фірма ТОВ «Данко».

Ti замовники, кого цікавлять не економія, а можливість укласти договір 3 наближеним постачальником, шукають будь-які способи уникнути аукціону. Одним із поширених методів зробити це $\epsilon$ поділ предмета закупівлі, оскільки закупівлі, вартість яких нижча за 50 тис грн можна проводити за прямими договорами й лише публікувати звіти про це в електронній формі. Так нечесні замовники без аукціону закуповують товари й послуги вартістю в сотні тисяч гривень, що підкреслює їх зневажливе ставлення до норм закону, хоча подібна практика прямо заборонена Законом України «Про публічні закупівлі» і за це передбачено штраф для замовника у розмірі від 25 тис до 50 тис грн. Але втілити в життя цю норму не так просто, хоча в грудні 2020 р. Кабінет 
Міністрів України прийняв постанову № 1266, у якій чітко визначив, що навіть коли підстав для початку моніторингу немає, керівник ДАС може призначити перевірку закупівлі, поділеної на частини [4].

Загалом, в Україні поширені наступні випадки зловживань державними замовниками при проведенні публічних закупівель: поділ предмету закупівлі на лоти для уникнення проведення конкурсних торгів; встановлення в документації тендерів вимог, що дискримінують та зменшують кількість потенційних учасників; неправомірне застосування переговорної процедури; умови договору про закупівлю відрізняються від змісту акцептованої пропозиції; відхилення переможців торгів за формальними ознаками; акцептування пропозиції, що перевищує ринкову ціну. Окремі замовники державних закупівель також створюють штучні проблеми для учасників тендерів, насамперед для так званих «небажаних» учасників. Антимонопольний комітет України (АМКУ) бореться з подібними порушеннями за допомогою штрафів, але це поки не дає бажаних результатів. Одним $з$ поширених методів порушень тендерних закупівель $\epsilon$ укладення змов й учасниками цих торгів, щоб зменшити ціну торгів. Як правило, їх учасники домовляються про максимальне обмеження ціни і визначають того, хто їх виграє. Особливо це проявляється при участі в цих торгах тільки двох учасників, які можуть бути пов'язаними між собою. Так, у 2019 р. АМКУ розкрив подібні змови у п'яти торгах, проведених Укрзалізницею, та наклав штраф на їх учасників на суму 60,8 млн грн.

Позитивом нової редакції Закону України «Про публічні закупівлі» став той факт, що вона надала учасникам закупівель можливість вносити корективи у свої тендерні пропозиції, так як це зменшило корупційні ризики. Це стосується лише помилок, що стосуються кваліфікаційних критеріїв і права підпису. Якщо замовник знаходить їх у найбільш економічно вигідній пропозиції, він дає право учаснику добу на виправлення. Така законодавча норма дозволила за 2020 рік зекономити 1,7 млрд грн, бо замовникам не довелося відхиляти найкращу пропозицію через формальні помилки.

Важливим чинником у боротьбі з фінансовими порушеннями при проведенні тендерних закупівель стало те, що їх перевірка протягом 2016-2021 pр. перетворилася на самостійну форму здійснення державного контролю з боку Державної аудиторської служби (ДАС), хоча й тут не все вдалося удосконалити. Зокрема, у липні 2020 р. Трансперенсі Інтернешнл Україна перевірила скільки над порогових закупівель потрапило у моніторинг Державної аудиторської служби у 20182019 рр. і виявила, що аудитори охопили перевірками лише 1,8 \% процедур. Тому доцільним $\epsilon$ створення в Україні окремої Агенції з тендерних закупівель, яка б взяла на себе функцію контролю за здійсненням публічних закупівель (за прикладом Польщі), а не розпорошувати цю функцію між кількома державними структурами, для яких вона $є$ не основною [5]. В цьому плані заслуговує на увагу й практика створення в Україні центральних закупівельних організацій (ЦЗО) при окремих міністерствах і відомствах, які забезпечують значну економію та мінімізують фінансові порушення при здійсненні тендерних закупівель [6]. ЦЗО формують команди з найкращих закупівельників, категорійних менеджерів, аналітиків і юристів. Вони не тільки добре знають як провести тендерну процедуру, а й чудово розбираються у самій специфіці предмету закупівлі. Створення подібних структур при всіх міністерствах і відомствах, а також на рівні обласних центрів допомогло б вирішити й таку проблему, як незацікавленість державних замовників публічних закупівель заощаджувати кошти. Проблема полягає в тому, що бюджетна сфера побудована таким чином, щоб повністю витратити свої кошти до Нового року. Саме тому державні замовники більше непокоються тим, як вчасно провести всі тендери, аніж купити якісні товари (послуги) за оптимальною ціною, допускаючи при цьому ті чи інші фінансові порушення. Найвідоміше з них - це надання замовлення потрібному учаснику з можливістю отримати від нього хабар.

Дуже серйозною проблемою у боротьбі з фінансовими порушеннями при здійсненні публічних закупівель поки залишається не завжди обгрунтоване втручання судових органів в організацію тендерних закупівель, що дає нечесним їх учасникам можливість порушувати фінансові умови тендерів. Зокрема, ТОВ «Хозхімсервіс» та ТОВ «Леман-Бетон», між якими АМКУ встановив змову та заборонив участь в тендерних закупівлях, зупинили це рішення в суді та виграли тендери на суму майже 500 млн грн. ТОВ Названі фірми мали засновників та працівників, які $є$ родичами, 
здійснювали діяльність за однією адресою і з одних IP-адрес, надавали один одному безвідсоткову фінансову допомогу тощо. Цей і подібні приклади не $є$ поодинокими, що вимагає належного реагування відповідних державних контролюючих органів на такі судові рішення.

На функціонування системи публічних закупівель суттєво впливають проблеми в діяльності фінансової системи України. Зокрема, недофінансування асигнувань розпорядникам коштів, їх нерівномірне надходження протягом року, особливо в четвертому кварталі. Як наслідок, процедури закупівель розпочинаються вже після отримання фінансових ресурсів, що нерідко призводить до їх формального та неякісного проведення закупівель або не проведення взагалі, та, відповідно, недотримання законодавства в частині публічних закупівель.

Учасник тендерних торгів може оскаржити їх результати, але для цього треба мати належні підстави, чого не зовсім дотримуються окремі суб' єкти оскарження. Донедавна їх кількість зростала, оскільки недобросовісні їх учасники прагнули не допустити до цих торгів «небажаних» учасників, так як плата за подання скарги була невеликою. Тепер, згідно з новою редакцією Закону України «Про публічні закупівлі» (2020р.), плата за подання скарги диференціюватиметься залежно від вартості закупівлі, предмету та етапу оскарження та визначатиметься не законом, а постановою уряду про затвердження плати за подання скарги до АМКУ.

Щодо порушень з боку учасників торгів, то у багатьох випадках у тендерах беруть участь близькі, часто навіть формально пов'язані особи. Нова редакція Закону України «Про публічні закупівлі» призупинила цей негативний процес, оскільки в тендерне законодавство введено поняття «пов’язані особи». Крім того, в тендерних закупівлях стали використовувати такі нові елементи, як: аномально низька ціна (АНЦ) тендерної пропозиції, електронний каталог, технічна специфікація до предмета закупівлі, пропозиція спрощеної закупівлі тощо, що не дозволяє подавати необгрунтовані скарги на результати тендерних закупівель. Проте треба взяти до уваги зауваження експертів щодо проблеми визначення аномально низької ціни тендерної пропозиції. АНЦ визначається електронною системою закупівель автоматично за умови наявності не менше двох учасників, які подали свої тендерні пропозиції щодо предмета закупівлі або його частини (лота). Але поки АНЦ працює не зовсім так, як планувалося, що сприяє фінансовим порушенням при проведенні публічних закупівель. Це пов'язано з тим, що поки немає чітких вимог, як саме учасник може підтвердити, що може продати за такою низькою ціною. Згідно досліджень фахівців, учасники тендерних закупівель надали розрахунки з АНЦ, щоб підкріпити свою цінову пропозицію, лише у 24 \% обгрунтувань.

Основним критерієм визначення переможців у тендерних закупівлях є ціновий, але сьогодні замовники можуть визначати й інші чинники, але останні мають важити не більше $30 \%$. Для України, яка суттєво відстає від країн $Є С$ щодо запровадження «зеленої» економіки, проблемою $є$ те, що при введенні у дію окремих положень нової редакції Закону України «Про публічні закупівлі» замовники стали користуватися неціновими критеріями навіть рідше, ніж раніше. Враховуючи, що Свропарламент 10.03.2021 p. підтримав формування механізму прикордонного вуглецевого коригування (СВАМ), тобто нового «вуглецевого» податку [7], Україна мусить у прискореному темпі проводити модернізацію не тільки теплових електростанції, цементних, металургійних та хімічних заводів, а й підприємства нафтопереробки, целюлозно-паперової промисловості та алюмінієвої галузі. Інакше продукція таких українських підприємств при експорті до ЄС буде обкладатися високим «вуглецевим» податком. Хоча наша країна й прийняла зобов'язання скоротити викиди парникових газів на 65 \% у порівнянні з рівнем 1990 р., але для цього поки не передбачені відповідні інвестиції, зокрема, й державні. Тому, при оцінці вартості життєвого циклу при проведенні публічних закупівель в Україні важливо приділити особливу увагу «зеленим» критеріям. Вартість життєвого циклу розраховується відповідно до методики, встановленої у тендерній документації. Поки ж, учасники тендерних закупівель 3 нетерпінням чекають, коли у Prozorro запрацює функціонал вартості життєвого циклу.

За придбання товарів, робіт і послуг до/без проведення процедур закупівель/спрощених закупівель, відповідно до вимог Закону України «Про публічні закупівлі», та укладення договорів, що передбачають оплату замовником товарів, робіт і послуг до/без проведення процедур закупівель/спрощених закупівель, визначених цим Законом, та за порушення вимог цього Закону службові (посадові) особи, уповноважена особа замовника та керівники замовників несуть 
відповідальність згідно із законами України. Зокрема, замовники платять 1700 грн за незначні порушення та 170 тис грн за значні порушення при здійсненні тендерних закупівель.

Якщо ДАС виявить порушення при здійсненні публічних закупівель, вона має право скласти протокол подати його в суд, вимагаючи розірвання будь-якого договору. Це потенційно дієвий метод боротьби із зловживаннями, але на практиці він майже не працює. Зокрема, фахівці DOZORRO проаналізували дані з системи державних закупівель і встановили (на 29.10.2020р.), що за попередні шість місяців ДАС провела моніторинг 3942 закупівель очікуваною вартістю понад 68 млрд грн. Із них у 3218 (81 \%) були виявлені порушення, а ще по 421 закупівлі тривав розгляд [8]. У 2017-2018 pp. ДАС публікувала на своєму офіційному сайті повідомлення про випадки, коли керівництво державних органів не реагувало на вимоги аудиторів. Утім, пізніше від цісї практики чомусь відмовилися, що дозволяє припустити про недостатню ефективність подібної діяльності ДАС. Це підкреслює той факт, що не дивлячись на вказані позитивні зміни, існуючий фінансовий контроль за публічними закупівлями має певні недоліки, які полягають у контролі тільки за завершеними тендерними процедурами. Відповідно, відсутні можливості втручання суб'єктів контролю у процес проведення публічних закупівель. Тому існуючі заходи контролюючих органів за результатами торгів поки не забезпечують повної прозорості тендерних закупівель, а також не сприяють попередженню виявлення порушень, передусім фінансових шахрайств. Відсутність належної автоматизації контролю, закритість даних про перебіг і результати перевірок обмежують всеосяжність контролю, адже доступність інформації у режимі реального часу забезпечує прозорість процесу публічних закупівель, зокрема й для громадських організацій.

Висновки та пропозиції. Недопущення фінансових порушень при проведенні публічних закупівель в Україні вимагає посилення фінансової відповідальності учасників цих закупівель. Існуючі заходи поки не забезпечують повної прозорості тендерних закупівель, а також не сприяють попередженню виявлення порушень, передусім фінансових. Відсутність належної автоматизації контролю, закритість даних про перебіг і результати перевірок обмежують всеосяжність контролю, зокрема, й для громадських організацій.

Заслуговує на увагу практика створення в Україні центральних закупівельних організацій при окремих міністерствах і відомствах, які забезпечують значну економію та мінімізують фінансові порушення при здійсненні тендерних закупівель. Подібні структури доцільно створити й на рівні обласних центрів, де здійснюються значні за обсягами тендерні закупівлі. Для зменшення проблем із ширшим залученням виконавців до проведення спрощених закупівель було б доцільним щорічно збільшувати поріг спрощених закупівель хоча б на рівень інфляції.

Для посилення фінансового контролю у сфері публічних закупівель необхідно ширше використовувати індикатори ефективності цих закупівель (нецінові критерії). Загалом, механізм здійснення публічних закупівель в Україні необхідно достосовувати до вимог ЄС, що дозволить нашій країні в майбутньому ставити питання щодо вступу в цю організацію. Для цього при оцінці вартості життєвого циклу при проведенні публічних закупівель в Україні важливо приділити особливу увагу не тільки ціні товару (послуги), а й «зеленим» критеріям, які починають активно використовуватися в країнах $\mathrm{CC.}$

\section{Джерела та література}

1. Задворний В. 43 млрд грн економії на рік. Ефект прозорих закупівель для країни. URL://www.epravda.com.ua/columns/2021/01/6/669779/

2. Ференц А. Друга закупівельна революція -

URL://www.epravda.com.ua/columns/2021/04/20/673170/
3. Парфенюк
О. План п’ятирічч:
що
вдалося
за
п’ять
років.

URL://www.epravda.com.ua/columns/2021/04/19/673140/

4. Хомяков Р. За гривню до прозорості: як замовники уникають аукціонів. 2021. URL://https://dozorro.org/blog/za-grivnyu-do-prozorosti-yak-zamovniki-unikayut-aukcioniv

5. Яременко С. Контроль публічних закупівель. Досвід для України. 2021. URL: https://dozorro.org/blog/kontrol-publichnih-zakupivel-dosvid-polshi-dlya-ukrayini 

6. Панаіотіді
C.
Що
дає
державі
централізація
закупівель?

URL://www.epravda.com.ua/columns/2021/04/219/673117/

7. Зелена металургія: чому в Україні не працює жоден фінансовий стимул для декарбонізації промисловості. URL://www.epravda.com.ua/projects/ekopromyslovist/2021/04/19/673017

8. Хомяков Р. Аудитом об стіну: як замовники ігнорують вимоги Держаудитслужби. URL:https://dozorro.org/blog/auditom-ob-stinu-yak-zamovniki-ignoruyut-vimogy-derzhauditsluzhbi

\section{References}

1. Zadvornyj V. (2021). 43 mlrd hrn ekonomii na rik. Efekt prozorykh zakupivel' dla krainy. [UAH 43 billion in savings per year. The effect of transparent procurement for the country]. URL://www.epravda.com.ua/columns/2021/01/6/669779/. [in Ukrainian].

2. Ferents A. (2021). Druga zakupivelna revoluciia - rik potomu. [The second procurement revolution was a year later]. URL://www.epravda.com.ua/columns/2021/04/20/673170/. [in Ukrainian].

3. Parfeniuk O. (2021). Plan piatyrichchia: shcho vdalosia za piaat' rokiv. [Five-year plan: what has been achieved in five years]. URL://www.epravda.com.ua/columns/2021/04/19/673140/. [in Ukrainian].

4. Khomiakov R. (2021). Za hryvnia do prozorosti: yak zamovnyky unykaiut' auktsioniv. [For the hryvnia to transparency: how customers avoid auctions]. URL://https://dozorro.org/blog/za-grivnyu-do-prozorosti-yak-zamovnikiunikayut-aukcioniv. [in Ukrainian].

5. Yaremenko S. 92021). Kontrol' publichnykh zakupivel'. Dosvid dla Ukrainy. [Public procurement control. Experience for Ukraine]. URL: https://dozorro.org/blog/kontrol-publichnih-zakupivel-dosvid-polshi-dlya-ukrayini. [in Ukrainian].

6. Panaiotidi S. (2021). Shcho daie derzhavi tsentralizatsiia zakupivel'? [What does the centralization of procurement give to the state?]. URL://www.epravda.com.ua/columns/2021/04/219/673117/. [in Ukrainian].

7. Zelena metalurhiia: chomu $\mathrm{v}$ Ukraini ne pratsiuie zhoden finansovyi stymul dla dekarbonizatsii promyslovosti. [Green metallurgy: why there is no financial incentive for decarbonization of industry in Ukraine]. URL://www.epravda.com.ua/projects/ekopromyslovist/2021/04/19/673017/. [in Ukrainian].

8. Khomiakov R. (2021). Audytom ob stinu: yak zamovnyky ihnoruiut' vymohy Derzhaudytsluzhby. [Audit against the wall: how customers ignore the requirements of the State Audit Office]. URL:https://dozorro.org/blog/auditom-ob-stinu-yak-zamovniki-ignoruyut-vimogy-derzhauditsluzhbi. [in Ukrainian].

Стаття надійшла до редакції 20.05.2021 p. 